\title{
Analysis of the Advantages to Develop Leisure Sports Tourism in Qingdao
}

\author{
Li Shumei $^{1}$ \\ ${ }^{1}$ P.E Department, Qingdao University of science and technology, China 266061
}

\begin{abstract}
In 2015 the Second World Leisure Expo is about to kick off in Laixi, Qingdao, bringing about the new development opportunity for urban leisure tourism by hosting such international events. The paper starts with defining the concept of leisure sports tourism to analyze the advantages of Qingdao in terms of developing leisure sports tourism so that we can promote the coordinated development of the tourism and sports industries in Qingdao.
\end{abstract}

Keywords: leisure, leisure sports tourism, development advantages, Qingdao

\section{Introduction}

With the rise of China's holiday economy, sports tourism has gradually become a trend in many parts of China. According to preliminary statistics, the number of people participating in sports fitness and recreation tourism activities accounts for $73.53 \%$ of domestic tourists, showing the huge market potential. Many provinces and cities have given priority to the development of sports tourism in the local tourism development plan. As is known, as the host venue for the 2008 Olympic Sailing Competition, Qingdao Olympic Sailing Center has become the bellwether for the local sports tourism. The Second World Leisure Expo will be opened soon in Laixi, Qingdao, naturally an opportunity to foster the leisure sports tourism into a brand of Qingdao tourism. So how to take this new development opportunity to give full play to the advantages of Qingdao leisure sports tourism is an issue worth studying.

\section{The definition of leisure sports tourism}

There is no consensus on the concept of leisure sports tourism among the academics currently. Having compared and analyzed the viewpoints of most scholars, the perspectives of $\mathrm{Gu}$ Xingquan and Yu Kehong are believed to be more comprehensive in defining leisure sports tourism, which refers to a form of activity that people leave their permanent residence to take part in positive physical activities in promoting physical and mental health for selfpleasure $^{[2]}$, and is an important form of leisure tourism. The combined development of sports and tourism in foreign countries has been over 100 years ${ }^{[3]}$, according to the forecast of World Leisure Organization, per capita GDP 2,000 US dollars is a threshold for rapidly growing demand for leisure, per capita GDP 3,000 US dollars will generally generate the demand for vacation and people's consumption structure at per capita GDP over 5000 US dollars will be tending to the "development type" and "enjoyment type", to be upgraded.

With the acceleration of China's urbanization and industrialization process, the urban residents feel increasingly stressed out due to intense competition and quickened pace of life, resulting in the declining health condition, people yearn for nature and health. The leisure sports tourism meets the demand for getting close to the nature of the modern people and the pursuit of health as well, featuring the free choice and participation of subject in activities, the excitement and entertainment of the activity content, and the diversity in forms and comprehensive utility of activities, it becomes a new hot spot for leisure tourists. Currently it has also been developed to a certain degree in China, such as in Hainan, sports has become an important catalyst for tourism in Hainan; North Lake Sport Tourism Economic Development Zone in Jilin Province has been bult as an important domestic leisure sports resort ${ }^{[4]}$. Qingdao, as the famous seaside tourist city, should seize the opportunity to develop sports leisure tourism on the strength of convenient conditions and advantages of resources for development of leisure sports tourism and the rare opportunity of being as the host city for the World Leisure Sports Meeting.

\section{Advantages of Qingdao for development of leisure sports tourism}

\subsection{Qingdao and good regional economy creating favorable environment for development of leisure sports tourism}

Leisure sports tourism development requires a certain economic strength. On one hand, the government must have financial strength to build and maintain the leisure sports facilities, on the other hand, people must be rich with "spare cash" at hand to be willing to spend on the leisure sports tourism. Over 20 years of steady development after reform and opening up, Qingdao has been comparatively economically developed among the domestic eastern coastal cities. According to statistics, the gross domestic product of Qingdao (GDP) in 2010 reached RMB 566.619 
billion, per capita disposable income of urban residents RMB 24,988, equivalent to 3993 USD. The Engel coefficient reflecting the living standard (the proportion of expenditure on food accounting for the total consumption expenditure) was $38.3 \%$. According to the standard proposed by the FAO, the Engel coefficient at 30-40\% means wealthy. The above data shows residents in Qingdao are better off, better than average of developing countries, which provides solid material guarantee for the development of urban leisure sports tourism. Moreover the development experience of tourism economy in developed countries suggests that at well-off stage, people like sightseeing tours; at better-off stage, people pursue leisure travel. Wealthy people choose leisure sports stage tour to better meet individual needs, as people live under pressure, suffering mental stress on weekdays, who need to release the inner tension in a short time. Leisure sports tourism can help people relax the body and mind, while exercising the body and mastering skills, which coincides with the current pursuit of high efficiency to get more pleasure and enjoy. People at better-off stage have the desire for leisure tourism objectively, leisure tourism combined and sport is the best way to achieve this. Additionally, the local economy is inseparable from the regional economic development. Qingdao is located in the Shandong Peninsula, closely linked to the economically developed regions of Yantai and Weihai, neighboring the developed South Korea and Japan across the sea, the good regional economy creates a favorable environment for Qingdao to develop leisure sports tourism.

\subsection{Qingdao's rich natural resources and good cultural tourism environment providing solid material guarantee for the development of leisure sports tourism}

Qingdao is a hilly seaside city located in the vital part of Shandong Peninsula with $862.64 \mathrm{~km}$ coastline, headland and bays alternating along the coastal area, Qingdao Bay, Huiquan Bay, Taiping Bay, Fushan Bay and Maidao Bay among 35 larger bays located in the urban center can be used as the event venues for marine sports. The marina and bases suitable for hosting large marine sports events include Sifang Coast Joy City marina, Tuan Island Garden Pier, Wheat Island, Laoshan District, the old man stone area, Yangkou area, Jimo Oceanspring Bay Area, etc. Six bathing beaches located in the center of Qingdao known for soft sand are fit for carrying out seaside sports events like swimming, sand sculpture, sandbeach activities. Qingdao boasts the warm temperate monsoon climate, cool in summer and warm in winter, with the annual average temperature at $12.3{ }^{\circ} \mathrm{C}$, annual average wind speed $5.4 \mathrm{~m} / \mathrm{s}$, seldom affected by the typhoon, the annual average wave height is not exceeding $0.4 \mathrm{~m}$, and the maximum wave height is $1.9 \mathrm{~m}$. In consideration of the climate and oceanographic conditions, Qingdao is suitable for carrying out marine sports. Qingdao has 69 large and small islands, al located less than 20 kilometers from the mainland, which are ideal places for island adventure, fishing and other sports. As a famous scenic spot, Laoshan Mountain located in the southeastern part of the city rises from the sea with long years of development and a wealth of resources to carry out various mountain leisure sports activities. The Dagu River, known as Qingdao's "Mother River" covers three districts, five lakes and nine nine wetlands, and is largest inland river in the Shandong Peninsula, after years of renovation, it has been transformed into a venue for the current fashionable lake sports, and recreational sports on the lake.

Table 1: Qingdao leisure sports tourism resource classification

\begin{tabular}{|c|c|}
\hline $\begin{array}{c}\text { Natural resources } \\
\text { for leisure sports } \\
\text { tourism }\end{array}$ & $\begin{array}{c}\text { Cultural } \\
\text { resources for } \\
\text { leisure sports } \\
\text { tourism } \\
\end{array}$ \\
\hline $\begin{array}{l}\text { Mountains, forest } \\
\text { resources-Laoshan } \\
\text { Mountain, Dazhu } \\
\text { Mountain, Xiaozhu } \\
\text { Mountain, Paikuo } \\
\text { Mountain, Langya } \\
\text { Mountain, Cangma } \\
\text { Mountain, Eshan } \\
\text { Mountain, Daze } \\
\text { Mountain, Mount } \\
\text { Tianzhu, Dasan, } \\
\text { Yunshan Mountain, } \\
\text { Daqing Mountain }\end{array}$ & $\begin{array}{l}\text { The Olympic } \\
\text { Sailing Center }\end{array}$ \\
\hline $\begin{array}{l}\text { Ocean, beach } \\
\text { resources-Qingdao } \\
\text { Golden Beach, Silver } \\
\text { Beach, beach, } \\
\text { Phoenix Island, } \\
\text { Tianheng Island, } \\
\text { Lingshan Bay, zhucha } \\
\text { Island, Big and Small } \\
\text { Guan Island, Zhaitang } \\
\text { Island, Sanping Island }\end{array}$ & $\begin{array}{l}\text { Olympic Sports } \\
\text { Center, Tiantai } \\
\text { Stadium, Guoxin } \\
\text { Stadium, Ocean } \\
\text { University, } \\
\text { Qingdao } \\
\text { University } \\
\text { Gymnasium }\end{array}$ \\
\hline $\begin{array}{l}\text { River Resources- } \\
\text { Dagu River, Jiao } \\
\text { River, Wind River, } \\
\text { Zhu River, Moshui } \\
\text { River }\end{array}$ & $\begin{array}{l}\text { World Leisure } \\
\text { Sports Park }\end{array}$ \\
\hline $\begin{array}{l}\text { Lake resources - Laixi } \\
\text { Lake, Moon Lake, } \\
\text { Jiangshan Lake, etc }\end{array}$ & $\begin{array}{l}\text { Laoshan Taoism } \\
\text { regimen }\end{array}$ \\
\hline $\begin{array}{l}\text { Waterfalls, caves } \\
\text { resources - Longtan } \\
\text { waterfall, Chaoyin } \\
\text { waterfall, Mingxia } \\
\text { cave, Mitain cave }\end{array}$ & \\
\hline $\begin{array}{l}\text { Snow resource - } \\
\text { Qingdao Belle SIYO } \\
\text { RINK, Jinshan Ski } \\
\text { Resort, Xiaozhu } \\
\text { Mountain Ski Resort, } \\
\text { etc }\end{array}$ & \\
\hline
\end{tabular}


Rich in cultural tourism resources, Qingdao is also a good place for leisure sports tourism. The Olympic Sailing Center as the landmark of "Sailing City" is a world-class sailing event venue, which has successfully hosted the 2008 Olympic sailing competition, Clipper, Volvo International Regatta and other major international events since its completion. "Qingdao International Sailing Week" as a well-known brand of sports tourism has struck root. A number of high-end sporting events and large-scale festivals have been held in the northern part of Qingdao around the Olympic Center in recent years. The basketball and football academy under construction will boom the sports competition training industry in Qingdao. Also there are sports tourism resources such as hot springs, health care, diving, wellness, hiking, golf, walking and martial arts, etc (see Table 1).

The table above shows that except the regional and particular sports tourism types in desert area, Qingdao has developed a variety of sports leisure tourism types for sports travel enthusiasts to choose from.

\subsection{World Leisure Tourism Conference to bring new development opportunities for urban leisure tourism}

The World Leisure Games with the theme of "sports leisure changes people's lifestyle" will be held in Laixi of Qingdao in mid-September 2015, the key projects of Laixi Lake, Jiangshan wetlands, and Dagu River leisure sports park will be built to form a shoreside park covering 60,000 acres and 70,000 acres with four-meter-wide bike lanes on the dam of both sides, where the events of fishing and biking and skating game will take place. Moreover the operation mode of World leisure Sports Meeting differs from the other international sports events, all venues are open to the public for free and all competition events will be divided professional and amateur groups, amateur contestants are free to sign up, greatly increasing the spectators and participators in the events.

\section{Conclusion}

The main trend of the future development of tourism is marked by the leisure as the main function, a destination as the center for basic stopover to expand sojourning travel including sightseeing tour of the surrounding area, sports, entertainment, shopping and other leisure activities, in other words, the leisure travel and holiday tourism will be featured product in the tourism market. The large summer festivals in Qingdao come to stage one after another, the leisure sports meeting following the Ocean Festival in early August and the international Beer Festival in the late August will certainly prolong the sojourning time of the "retention in travel process". Therefore, Qingdao should vigorously promote the advantages of leisure sports tourism, seize the opportunity of leisure sports meeting to be held in Laixi to develop marketable tourism product, combining leisure sports tours with other sighting tours, festivals exhibition tours to promote the development of leisure sports tourism in Qingdao.

\section{Acknowledgment}

We gratefully thank the support of this investigation by Qingdao University of Science \& Technology teaching reform project (project supported by the young) 2014 .

\section{References}

[1] Li Xiangru, Ling Ping, Lu Feng. Introduction to Leisure Sports [M] Beijing: Higher Education Press, 2011.157167.

[2] Gu Xingquan, Yu Kehong. Study on Hangzhou Leisure Sports Tourism Development Prospects [J] Zhejiang Sport Science, 2005 (5): 89

[3] Liu Zaisen, Research on Development of Qingdao leisure tourism resources [D]. Qingdao University Master's thesis, 2011.12

[4] Li Ping, Discussion on Development of Qingdao coastal leisure sports tourism $[\mathrm{J}]$. Coastal Engineering, 2002 (3) .69 